\title{
EVALUASI PELATIHAN DASAR CALON PEGAWAI NEGERI SIPIL DALAM MENDUKUNG TERWUJUDNYA SUMBERDAYA MANUSIA PROFESIONAL BERKARAKTER
}

\author{
Rahmi Astuti Rohaini ${ }^{1}$, Nandang Hidayat ${ }^{2}$, Entis Sutisna ${ }^{2}$ \\ ${ }^{1}$ Pegawai pada Pusdiklat SDM LHK, Bogor, Jawa Barat \\ ${ }^{2}$ Program Pascasarjana Universitas Pakuan, \\ Email: pasca@unpak.ac.id
}

\begin{abstract}
The research aims to evaluate the effectiveness of CPNS LATSAR at the level of; Reaction, Learning Activity, Behavior and Result. The research was conducted at CEFHRET Bogor. Questions and Interviews were used in collecting the data. The data collected by using Likert Scale as well. The qualitative description was taken as the technique to analyzing the data. The evaluation was done by using the model of Kircpatric. The results of the evaluation at the level of; reaction, the learning activity, and the participants' behavior were indicating that the training implemented effectively. It was not running effectively when the teamwork required. The training was completed effectively according to the Direct Superior's evaluation. The conclusion is that CPNS LATSAR effectively conducted.
\end{abstract}

Keywords: CPNS Latsar, Training Effectiveness, Kirkpatrick Model Evaluation.

\begin{abstract}
ABSTRAK
Penelitian ini bertujuan untuk mengevaluasi tentang Efektivitas Latsar CPNS Pusdiklat SDM LHK pada tingkat reaksi, pembelajaran, perilaku dan hasil. Evaluasi dilakukan dengan menggunakan model Kirckpatrick. Penelitian dilaksanakan di Pusat Diklat SDM Lingkungan Hidup dan Kehutanan Bogor. Populasi penelitian adalas peserta Latsar CPNS angkatan 4 tahun 2018. Pengumpulan data untuk setiap variabel menggunakan skala Likert. Teknik analisis menggunakan Analisis Deskriptif. Berdasarkan hasil evaluasi tingkat reaksi, diketahui peserta menyatakan pelatihan telah dilaksanakan secara efektif. Berdasarkan hasil evaluasi pada tingkat pembelajaran peserta menyatakan pelatihan telah dilaksanakan secara efektif. Berdasarkan hasil evaluasi pada tingkat perilaku peserta menyatakan telah dilaksanakan secara efektif. Khusus untuk partisipasi dalam kerja tim, responden menilai belum optimal yaitu cukup efektif. Berdasarkan hasil evaluasi pada tingkat hasil atasan langsung peserta pelatihan menyatakan telah efektif. Dengan demikian dapat disimpulkan bahwa hasil evaluasi terhadap Latsar CPNS telah dilakukan secara efektif.
\end{abstract}

Kata kunci : Latsar CPNS, Efektivitas Pelatihan, Evaluasi Model Kirckpatric,

\section{PENDAHULUAN}

Negara Kesatuan Republik Indonesia dari Sabang sampai Merauke memiliki semua prakondisi untuk mewujudkan visi negara sebagaimana tertuang dalam Pembukaan UndangUndang Dasar Negara Republik Indonesia Tahun 1945, yang ditandai dengan kekayaan alam yang melimpah, potensi sumber daya manusia, peluang pasar yang besar dan demokrasi yang relatif stabil. Namun prakondisi yang sudah terpenuhi itu belum mampu dikelola secara efektif 
dan efisien, sehingga Indonesia masih tertinggal dari cepatnya laju pembangunan global dewasa ini. Pegawai Negeri Sipil (PNS) memiliki peranan yang menentukan dalam mengelola prakondisi tersebut. Sejumlah keputusan-keputusan strategis mulai dari memformulasi kebijakan sampai pada penetapannya dalam berbagai sektor pembangunan ditetapkan oleh PNS. Untuk malaksanakan hal tersebut, diperlukan sosok PNS yang profesional, yaitu PNS yang mampu memenuhi standar kompetensi jabatannya sehingga mampu melaksanakan tugas jabatannya secara efektif dan efisien.

Mengingat peran PNS yang cukup penting maka diperlukan sosok PNS profesional yang mampu memenuhi standar jabatannya sehingga dapat bekerja secara efektif dan efisien. Untuk dapat membentuk seorang PNS yang profesional sebagaimana dimaksud di atas diperlukanlah pembinaan melalui pemberian pelatihan

\section{Evaluasi Efektivitas Program Pelatihan}

Konsep pelatihan telah banyak didefinisikan oleh para ahli pendidikan, salah satunya menurut Notoatmodjo (2009:34), pelatihan atau training merupakan bagian dari suatu proses pendidikan yang bertujuan untuk meningkatkan kemampuan atau keterampilan karyawan dalam suatu institusi. Pelatihan diartikan oleh Siringoringo (2012:51) sebagai upaya untuk meningkatkan pengetahuan, keterampilan, dan sikap atau sering disebut juga dengan kompetensi yang pada akhirnya dapat bermanfaat bagi peserta pelatihan dalam melaksanakan tugas di instansinya sehari-hari. Menurut Mustofa Kamil (2010:13) tujuan program pelatihan adalah untuk meningkatkan kompetensi, mencapai tingkat kompetensi tertentu yang dipersyaratkan, dan menutup kesenjangan (gap) kompetensi antara yang dimiliki saat ini dengan kompetensi yang dituntut untuk mampu melaksanakan tugas pekerjaan secara efektif.

Sementara menurut Rivai (2006:183), pelatihan secara singkat didefinisikan sebagai suatu kegiatan untuk meningkatkan kinerja saat ini dan kinerja di masa mendatang. Pelatihan adalah proses secara sistematik mengubah tingkah laku karyawan untuk melaksanakan pekerjaan saat ini. Sejalan dengan pendapat tersebut, Malayu (2004:63) menyatakan bahwa pelatihan merupakan sebuah proses mengajarkan pengetahuan dan keahlian tertentu, serta sikap agar karyawan semakin terampil dan mampu melaksanakan tanggungjawabnya dengan baik, sesuai standar.

Berdasarkan uraian teori di atas, maka dapat disintesakan bahwa konsep pelatihan adalah proses secara sistematik mengubah tingkah laku peserta pelatihan untuk melaksanakan tugas pokok dan fungsi yang akan dihadapi, dengan cara melakukan perubahan pengetahuan, perilaku, sikap dan keahlian, sesuai dengan bidang tugasnya.

\section{Efektivitas pelatihan}

Hikmawati (2015:47) meliputi efektivitas dari perspektif individu, efektivitas dari perspektif kelompok dan efektivitas dari perspektif organisasi. Hal ini mengandung arti bahwa efektivitas memiliki tiga tingkatan yang merupakan satu kesatuan yang saling melengkapi dimana efektivitas perspektif individu berada pada tingkat awal untuk menuju efektivitas kelompok maupun efektivitas organisasi. Streers (1980) dalam Fuad (2011:56) menyatakan bahwa efektivitas selalu diukur berdasarkan prestasi, produktivitas, laba dan sebagainya.

Kaswan (2011:122) menyebutkan bahwa program pelatihan terbukti efektif jika pelatihan tersebut mampu meningkatkan kinerja, memperbaiki semangat kerja, mendongkrak potensi organisasi. Noe (2002:141) juga menambahkan bahwa pada umumnya suatu program pelatihan dikatakan efektif jika hasil dari pelatihan ini dapat memberikan manfaat bagi organisasi dan peserta pelatihan.

Berdasarkan uraian teori di atas, maka dapat disintesakan bahwa efektivitas pelatihan adalah pemanfaatan sumberdaya, sarana dan prasarana pelatihan yang secara sadar dikelola untuk mencapai tujuan pelatihan yang telah ditetapkan Pelatihan dikatakan efektif apabila 
memenuhi kriteria yaitu: peserta puas terhadap proses pelatihan, terdapat peningkatan pengetahuan, terdapat perubahan perilaku dalam bekerja, dan hasil perubahan tersebut memberi manfaat bagi organisasi tempat kerja.

\section{Evaluasi Program Pelatihan}

Menurut Widoyoko (2009:115), fungsi utama evaluasi adalah memberikan data informasi yang benar mengenai pelaksanaan suatu pelatihan sehingga penyelenggaraan pelatihan tersebut dapat mengambil keputusan yang tepat, apakah pelatihan itu akan diteruskan, ditunda atau sama sekali tidak dilaksanakan lagi. Noe (2002:119) mengartikan evaluasi program pelatihan sebagai suatu proses pengumpulan keluaran yang dibutuhkan untuk menilai apakah sebuah program pelatihan sudah efektif atau belum.

Sedangkan menurut Goldstein (1993:87), evaluasi program pelatihan mempunyai arti sebagai suatu proses pengumpulan informasi secara sistematis, baik informasi yang sifatnya deskriptif maupun judgemental, yang diharapkan dapat membantu dalam mengambil keputusan secara efektif, dalam hal pemilihan, adopsi, maupun modifikasi terhadap berbagai kegiatan operasional dalam organisasi.

Berdasarkan uraian teori di atas, dapat disintesakan bahwa evaluasi program pelatihan adalah mengumpulkan, mengolah, menganalisa, atau menafsirkan tentang efektivitas program pelatihan sebagai dasar pengambilan keputusan.

\section{Evaluasi Pelatihan Model Kirckpatrick}

Kirkpatrick, D., L. \& Kirkpatrick J., D. (2006:21) mengemukakan tiga alasan spesifik dalam melakukan evaluasi program pelatihan, yaitu: untuk menetapkan keberadaan anggaran pelatihan dengan memperlihatkan bagaimana program pelatihan tersebut berkontribusi pada tujuan dan sasaran organisasi; untuk menentukan apakah suatu program pelatihan dilanjutkan atau tidak; serta untuk memperoleh informasi mengenai bagaimana cara meningkatkan program pelatihan di masa datang. Metode evaluasi empat level merepresentasikan sebuah sekuen dari setiap tahapan untuk mengevaluasi program pelatihan. Maksud dari sekuen adalah setiap level harus dilakukan secara bertahap. Hal tersebut karena setiap level dalam model empat level adalah penting dan setiap level memberi dampak pada level berikutnya. Empat level tersebut adalah: Level 1- Reaction (Reaksi), Level 2- Learning (Pembelajaran), Level 3Behavior (Perilaku), dan Level 4- Results (Hasil/Dampak).

\section{Pelatihan Dasar (Latsar) CPNS}

Saefudin (2014:107) dalam inovasi kurikulum yakni tahap merencanakan materi kurikulum pelatihan terdapat beberapa landasan utama dalam menyusun kurikulum antara lain : pertama, landasan filosofis, bahwa pengembangan kurikulum harus memiliki filsafat yang dianut oleh masyarakat yang akan dikembangkan. Dahar (1998:117) metode yang digunakan menjadi berbeda yaitu dengan pendekatan student centered, problem solving, dan terkahir competency based training, yaitu pelatihan berbasis kompetensi.

Berdasarkan uraian teori di atas, maka dapat disintesakan bahwa Latsar CPNS dikatakan efektif apabila peserta pelatihan memiliki reaksi positif (kepuasan) terhadap proses pelatihan, terdapat peningkatan pengetahuan peserta, terdapat peningkatan perubahan perilaku kerja, pelatihan memberi manfaat atau dampak positif terhadap organisasi.

\section{METODE PENELITIAN}

Penelitian ini merupakan penelitian evaluasi (evaluation study) untuk menilai efektivitas suatu program yang sedang atau sudah dilakukan dengan tujuan untuk memperbaiki atau meningkatkan program tersebut. Metode penelitian yang digunakan adalah metode evaluasi 
model Kirkpatrick dengan dimensi yang diukur melalui empat tingkat yakni tingkat Reaksi (reaction level), tingkat pembelajaran (learning level), tingkat perilaku (behavior level), tingkat hasil (result level).

Penelitian ini dilaksanakan di Pusdiklat SDM LHK yang berlokasi di J1. Ishak Juarsa Gunung Batu Bogor.

\section{HASIL PENELITIAN}

Berdasarkan data diperoleh gambaran untuk masing-masing butir pernyataan hasil penelitian yang berkaitan dengan Mengembangkan Pola Kerja. Dari 5 butir pernyataan, nilai Sangat Setuju diperoleh pada butir pernyataan "Mampu mengembangkan pola kerja baru dalam menyelesaikan tugas" sebesar $80 \%$, responden menyatakan sangat setuju untuk butir pernyataan "Pelatihan telah meningkatkan produktivitas bekerja" sebesar 75\%". Responden menyatakan Sangat Setuju untuk pernyataan "Pelatihan berbasis kompetensi yang diberikan sangat membantu peserta pelatihan menjalankan tupoksi" sebesar $70 \%$.

Berdasarkan data diperoleh gambaran untuk masing-masing butir pernyataan hasil penelitian yang berkaitan dengan Kontribusi Terhadap Organisasi. Dari 5 butir pernyataan, nilai tertinggi diperoleh pada butir pernyataan "Kinerja yang diberikan peserta pelatihan telah pemperkuat nilai-nilai yang dianut organisasi" sebesar $75 \%$.

Berdasarkan data diperoleh gambaran untuk masing-masing butir pernyataan hasil penelitian yang berkaitan dengan Kecepatan dan Kecermatan Dalam Bekerja masing-masing memberikan prosentase sebesar $70 \%$ untuk pernyataan " Dalam melaksanakan tugas pekerjaan, saya selalu mencari dan melakukan penyempurnaan agar hasil bertambah baik" dan pernyataan "Selalu berusaha meminimalisir kesalahan dalam melaksanakan pekerjaan" sebesar 70\%.

\section{PEMBAHASAN}

\section{Karakteristik Responden}

Mayoritas usia responden dalam penelitian ini berada pada rentang usia 20-30 tahun yaitu sebanyak $41,30 \%$ kurang dari 25 tahun, sedangkan sisanya 58,06\% berada pada rentang usia 25-30 tahun. Hal ini disebabkan batasan usia peneriaam CPNS yang tidak boleh lebih dari 30 tahun.

Pendidikan terakhir peserta pelatihan sejumlah 90,32 \% adalah sarjana S1 dan 9,67\% S2. Hal ini dikarenakan persyaratan untuk diterima sebagai CPNS Golongan 3 adalah lulusan sarjanan S1. Dari table 5 bisa dilihat bahwa sebesar 64,51\% peserta Latsar telah memiliki pengalaman bekerja sebelum masuk sebagai CPNS. Dengan demikian bisa diharapkan bahwa pengalaman bekerja tersebut dapat membantu peserta untuk lebih mudah beradaptasi di lingkungan bekerja atau organisasi yang baru.

\section{Evaluasi Efektivitas Pelatihan}

Sebagaimana disampaikan oleh Kirckpatrick (2006) evaluasi terhadap reaksi peserta pelatihan berarti mengukur kepuasan peserta pelatihan. Sebagaimana diungkapkan oleh Satrio dkk (2007:113), pada dasarnya evaluasi pelatihan pada tingkat reaksi dilakukan untuk mengukur tingkat kepuasan peserta terhadap program pelatihan yang diikuti berdasarkan persepsi dan apa yang dirasakan oleh peserta.

Terhadap indikator Ketepatan Metode Pelatihan peserta menyatakan bahwa metode pelatihan yang digunakan efektif, sedangkan 16,13\% menyatakan cukup efektif. Hal ini sesuai dengan teori yang disampaikan oleh Dessler dalam Rahardjo (2008:179) metode pelatihan adalah sebagai suatu cara atau jalan untuk membantu peserta memahami substansi yang disampaikan juga untuk memperbaiki dan meningkatkan kemampuan peserta pelatihan. Hasil 
temuan ini membuktikan bahwa metode pelatihan yang dipergunakan selama Latsar CPNS yakni berupa pengkondisian suasana kelas sesuai dengan materi pada tiap sesi, melakukan kegiatan praktik, diskusi kelompok untuk membahas studi kasus, materi yang disampaikan diperkuat dengan multimedia telah telah dilaksanakan secara efektif.

Terhadap indikator Kompetensi Mengajar Widyaiswara peserta menyatakan bahwa kompetensi widyaiswara efektif dalam menyampaikan materi pelatihan. Kompetensi widyaiswara sangat berpengaruh terhadap efektivitas pelatihan, sebagaimana disampaikan oleh Djohar (2006:130) bahwa kompetensi pendidik terkait dengan kewenangan melaksanakan tugasnya, dan kompetensi pedagogis yang berkaitan dengan fungsi pendidik dalam memperhatikan perilaku peserta didik belajar. Hasil temuan ini cukup membuktikan bahwa widyaiswara yang mengajar pada Latsar CPNS memiliki kompetensi yang cukup memadai dikarenakan widyaiswara mengenal karakteristik peserta didik, menunjukkan tanggung jawab dan etos kerja tinggi, menguasai meteri pelatihan, mengembangkan materi pendukung dan menyampaikannya dengan kreatif ditunjang teknologi informasi.

Penilaian responden terhadap indikator Kondisi Lingkungan Pelatihan peserta menyatakan bahwa lingkungan pelatihan cukup kondusif dalam menunjang proses pembelajaran. Hasil temuan ini cukup membuktikan bahwa memastikan kondisi lingkungan dengan baik akan mampu menciptakan proses pembelajaran yang nyaman, sehingga peserta pelatihan sangat terbantu. Beberapa yang dilakukan diantaranya adalah : memperhatikan suhu udara di ruang kelas, ventilasi, intensitas cahaya, kebisingan, keselamatan barang milik peserta dan ditunjang dengan sarana dan prasarana yang memadai. Lingkungan pelatihan merupakan aspek yang perlu diperhatikan dalam menentukan proses pembelajaran. Menurut Kustini (2004:132) menjelaskan satu pola pikir mengenai pengaruh lingkungan pelatihan akan mempengaruhi pemberian pelatihan secara keseluruhan. Lingkungan pelatihan yang baik dan mendukung akan membantu proses pembelajaran. Hal senada disampaikan oleh Hariyatie (2005:112) bahwa lingkungan pelatihan menentukan aktivitas pelatihan yang mereka ikuti dan berpengaruh terhadap kemampuan penerapannya.

\section{Pembahasan Hasil Evaluasi Latsar CPNS Tingkat Pembelajaran}

Dari data mengungkapkan bahwa peserta Latsar CPNS terbantu dengan adanya materi pelatihan yang disampaikan. Terhadap indikator Pemahaman Manfaat Materi Pelatihan, peserta menyatakan efektif sebab materi yang diperoleh telah bermanfaat dengan menambah pengetahuan tentang tugas dan fungsi PNS, meningkatkan keterampilan, memperbaiki sikap dalam bekerja dan mendukung dalam melaksanakan tugas. Untuk mengukur tingkat pembelajaran, dilakukan juga tes tertulis sebelum pelatihan (Pretest) dan sesudah pelaksanaan pelatihan (Posttest) dengan memberikan serangkaian pertanyaan dalam bentuk multiple choise. Berdasarkan hasil uji statistic menggunakan uji t sebagaimana pada lampiran 8 , terdapat perbedaan yang signifikan antara nilai sebelum dilakukan pretest dan sesudah dilakukan postest. Artinya bahwa telah terjadi peningkatan pengetahuan, keterampilan dan sikap pada peserta Latsar CPNS setelah mereka mengukuti pelatihan tersebut. Hasil uji statistik diatas selaras dengan yang dikemukakan oleh

Salman (2012:216) sebelumnya yang menyatakan bahwa salah satu tujuan dari belajar adalah adanya peningkatan pengetahuan dan Pratt (1998:87) yang mendefinisikan belajar sebagai peningkatan dalam pengetahuan.

\section{Pembahasan Hasil Evaluasi Latsar CPNS Tingkat Perilaku}

Notoatmodjo (2009:63) mendefinisikan perilaku sebagai suatu reaksi seseeorang terha dap lingkungannya. Terkait indicator Perubahan Sikap Kerja diperoleh bahwa 64,51\% peserta menyatakan bahwa pelatihan telah mampu merubah sikap kerja secara efektif, sedangkan $35,49 \%$ menyatakan cukup efektif. Hal ini dapat diperkuat dengan hasil wawancara dengan 
peserta pelatihan yang menyatakan bahwa program pelatihan telah membantu mereka memperbaiki sikap dalam bekerja, melakukan pekerjaan berlandaskan komitmen mutu, serta termotivasi untuk lebih cermat dalam mengambil tindakan. Hasil wawancara dengan atasan langsung peserta pelatihan diperoleh hasil bahwa peserta pelatihan mampu bekerja sesuai dengan arahan yang telah diberikan oleh pimpinan dan mengkomunikasikan hasil pekerjaannya dengan sopan santun. Dengan demikian dapat dikatakan bahwa Latsar CPNS telah mampu merubah sikap kerja peserta pelatihan menjadi lebih baik. Hal ini sesuai dengan teori yang dikemukakan oleh Jewel dan Siegell (1998:68)) mengemukakan bahwa sikap terhadap karakteristik pekerjaan merupakan tingkah laku atau perasaan, terhadap suatu kegiatan yang tercermin dalam perasaan senang, menerima atau setuju sehingga hasil kegiatan yang dilakukan tersebut akan mempunyai nilai kepuasan yang tinggi. Apabila memiliki sikap kerja yang posditif maka akan sangat membantu dalam pelaksanaan tugas poko dan fungsi seorang CPNS.

Berkaitan dengan indikator Komunikasi, peserta menyatakan bahwa setelah mengikuti pelatihan kemampuan komunikasi menjadi lebih baik (menyatakan efektif) sebesar 74,17\% dan lebih percaya diri. Komunikasi pada hakekatnya adalah proses penyampaian pikiran atau perasaan oleh komunikator kepada komunikan. Sebagaimana disampaikan Steensma(2010:321) bahwa komunikasi adalah proses penyampaian informasi, gagasan, fakta, pikiran dan perasaan dari satu orang ke orang lain.

Penilaian responden terhadap indikator Penerapan Pengetahuan setelah mengikuti pelatihan diperoleh hasil $61,29 \%$ peserta menyatakan bahwa program pelatihan telah efektif membantu peserta dalam menerapkan pengetahuan, sedangkan $38,71 \%$ menyatakan cukup efektif. Lumbantobing (2011:24) menyatakan dalam sebuah organisasi kerja, penerapan pengetahuan adalah salah satu proses utama di dalam knowledge management yang ditujukan untuk memaksimalkan pemanfaatan pengetahuan melalui pendistribusian pengetahuan kepada anggota yang membutuhkan.

Penilaian responden terhadap Kemampuan Pelaksanaan Tugas diperoleh bahwa 77,41\% peserta menyatakan bahwa pelatihan telah membimbing peserta mampu melaksanakan tugas secara efektif, sedangkan 22,59\% menyatakan cukup efektif. Hal ini diperkuat dengan hasil wawancara dengan peserta pelatihan bahwa mereka lebih percaya diri dengan kemampuan yang dimiliki serta lebih percaya diri untuk melaksanakan tugas yang diberikan pimpinan.

Penilaian responden terhadap kemampuan Partisipasi Dalam Kerja Tim setelah mengikuti pelatihan diperoleh hasil $45,16 \%$ peserta menyatakan bahwa program pelatihan telah efektif membantu peserta dalam kerja tim, sedangkan 54,84\% menyatakan cukup efektif.

\section{Pembahasan Hasil Evaluasi Latsar CPNS Tingkat Hasil}

Berdasarkan hasil penelitian yang dilakukan, dapat diketahui bahwa penilaian responden selaku atasan langsung peserta pelatihan, memberikan hasil yang positif yakni kemampuan Mengembangkan Pola kerja diperoleh bahwa 83,87\% menyatakan bahwa pelatihan telah mampu mengembangkan pola kerja secara efektif, sedangkan $16,13 \%$ menyatakan cukup efektif.

Berdasarkan hasil penelitian yang dilakukan, dapat diketahui bahwa penilaian responden memberikan hasil yang positif yakni kemampuan Kontribusi Terhadap Organisasi diperoleh bahwa $80,64 \%$ peserta menyatakan bahwa pelatihan telah mampu mengembangkan pola kerja secara efektif, sedangkan $19,36 \%$ menyatakan cukup efektif.

Atasan langsung peserta pelatihan menyatakan bahwa peserta Latsar CPNS telah memiliki Kecepatan dan Kecermatan Dalam Bekerja. Responden memberikan nilai efektif sebesar 74,2\%, sehingga menunjukkan bahwa peserta Latsar CPNS setelah mengikuti pelatihan mampu memberikan dampak positif terhadap organisasi tempat kerja. 
Berdasarkan hasil wawancara dengan atasan langsung peserta Latsar CPNS disampaikan pula hal-hal yang belum optimal terkait hasil dari pelatihan tersebut antara lain belum mampu sepenuhnya menerapkan etika dan moral CPNS karena perlu pematangan lebih lanjut, komunikasi yang belum sepenuhnya efektif karena adanya rasa sungkan dengan pimpinan sehingga menghambat kinerja CPNS.

\section{SIMPULAN}

Berdasarkan analisis terhadap data hasil penelitian dapat disimpulkan bahwa :

1. Secara umum Latsar CPNS telah dilaksanakan secara efektif. Hai ini bisa dilihat dari penilaian responden terhadap masing-masing tingakat evaluasi sebagai berikut:

a. Evaluasi tingkat reaksi (reaction)

Berdasarkan hasil evaluasi tingkat reaksi, diketahui rata-rata peserta pelatihan merasa puas dan menyatakan pelatihan telah dilaksanakan secara efektif terkait dengan ketepatan metode pelatihan $(83,87 \%)$, kompetensi mengajar widyaiswara $(90,32 \%)$, kondisi lingkungan pelatihan $(80,64 \%)$. Peserta memberikan nilai cukup efektif yang berarti belum optimal untuk indicator hubungan social dalam pelatihan $(67,75 \%)$.

b. Evaluasi pada tingkat pembelajaran (Learning)

Latsar CPNS mampu meningkatkan pengetahuan peserta pelatihan. Responden menyatakan bahwa Latsar CPNS telah dilaksanakan secara efektif terkait dengan pemahaman manfaat materi pelatihan $(83,87 \%)$, penguasaan materi pelatihan $(67,74 \%)$, pemahaman fungsi materi pelatihan $(87,09 \%)$.

c. Evaluasi level perilaku (behaviour)

Latsar CPNS mampu mengubah perilaku peserta pelatihan dalam melaksanakan tugas pokok dan fungsi di organisasi tempat kerjanya. Hal ini bisa dilihat dari pernyataan responden yang menilai bahwa Latsar CPNS telah dilaksanakan secara efektif terkait dengan perubahan sikap kerja $(64,51 \%)$, kemampuan komunikasi $(74,19 \%)$. Penerapan pengetahuan $(61,29 \%)$, kemampuan pelaksanaan tugas ( $77,41 \%$ ). Khusus untuk partisipasi dalam kerja tim, responden menilai belum optimal yaitu cukup efektif sebesa 54,84\%.

d. Evaluasi level hasil (result).

Atasan langsung peserta Latsar CPNS selaku responden menyatakan bahwa Latsar CPNS telah dilaksanakan secara efektif. Hal ini dapat dilihat dari penilaian responden terkait kemampuan mengembangkan pola kerja $(83,87 \%)$, kontribusi terhadap organisasi $(80,64 \%)$ dan kecepatan dan kecermatan dalam bekerja $(74,20 \%)$.

\section{DAFTAR PUSTAKA}

Dahar, Ratna Wilis. 1998. Teori-Teori Belajar. Jakarta : Gramedia Pustaka Utama.

Djohar, A. 2007. Pendidikan Teknologi dan Kejuruan. Dalam Ilmu dan Aplikasi Pendidikan. Bandung: Pedagogiana Press. Hal. 1285-1300.

Fuad, M. dkk, 2011, Pengantar Bisnis, Jakarta:PT Gramedia Pustaka Utama,

Goldstein, Irwin L., Ford J. Kevin., 1993, Training in Organization : Fourth Edition. Canada: Wadsworth GroupThomson Learning

Kaswan. 2011. Pelatihan dan Pengembangan. Bandung: Penerbit Alfabeta

Kirkpatrick, D. L. 2006. Kirkpatrick's Training Evaluation Model.

KirkpatricK, James D. and WenDy K. KirKpatricK. 2009. Creating a PostTraining Evaluation Plan; Jurnal Learning \& DeveLopment Sanfransisco : Berret-Koehler Publisher.Inc

Lumbantobing, Paul. 2011. Manajemen Knowledge Sharing Berbasis Komunitas. Bandung: Knowledge Management Society Indonesia 
Mustofa. 2010 Model Pendidikan Dan Pelatihan: Konsep dan Aplikasi, Bandung: Alfabeta.

Notoatmodjo, Soekidjo,2009. Pengembangan Sumberdaya Manusia. Jakarta:PT. Rineka Cipta.

Robbins, Stephen. P. 2006. Prilaku Organisasi. Edisi Bahasa Indonesia. Jakarta:PT. Indeks Kelompok Gramedia.

Rivai, Veithzal. 2009. Manajemen Sumber Daya Manusia Untuk Perusahaan Dari Teori ke Praktik. Jakarta: Raja Grafindo Persada

Satrio,Teguh dan Andree MKP. 2007. How to Measure 4 Levels of Training Evaluation. Jakarta : Intelectual Capital Publishing.

Saefudin, Udin. 2014. Inovasi Pendidikan. Bandung: Alfabeta Sudjana.

Steensma, Herman and Karni Groeneveld. 2010. Evaluating a Training Using the Four Levels Model. Journal of Workplace Learning, Vol. 22,

Siringoringo,R.H.2012. Evaluasi Diklat. Artikel diunduh dari www.pusdiklatwas.bpkp.go.id

Widoyoko, S. Eko Putro.2012. Evaluasi Program Pembelajaran: Panduan Praktis Bagi Pendidik dan Calon Pendidik. Yogyakarta : Pustaka Pelajar. 